\title{
Industry life cycles in Dutch manufacturing
}

Citation for published version (APA):

van Dijk, M. A. (1998). Industry life cycles in Dutch manufacturing. MERIT, Maastricht Economic Research Institute on Innovation and Technology. MERIT Research Memoranda No. 010 https://doi.org/10.26481/umamer.1998010

Document status and date:

Published: 01/01/1998

DOI:

10.26481/umamer.1998010

Document Version:

Publisher's PDF, also known as Version of record

\section{Please check the document version of this publication:}

- A submitted manuscript is the version of the article upon submission and before peer-review. There can be important differences between the submitted version and the official published version of record.

People interested in the research are advised to contact the author for the final version of the publication, or visit the DOI to the publisher's website.

- The final author version and the galley proof are versions of the publication after peer review.

- The final published version features the final layout of the paper including the volume, issue and page numbers.

Link to publication

\footnotetext{
General rights rights.

- You may freely distribute the URL identifying the publication in the public portal. please follow below link for the End User Agreement:

www.umlib.nl/taverne-license

Take down policy

If you believe that this document breaches copyright please contact us at:

repository@maastrichtuniversity.nl

providing details and we will investigate your claim.
}

Copyright and moral rights for the publications made accessible in the public portal are retained by the authors and/or other copyright owners and it is a condition of accessing publications that users recognise and abide by the legal requirements associated with these

- Users may download and print one copy of any publication from the public portal for the purpose of private study or research.

- You may not further distribute the material or use it for any profit-making activity or commercial gain

If the publication is distributed under the terms of Article $25 \mathrm{fa}$ of the Dutch Copyright Act, indicated by the "Taverne" license above, 


\title{
Industry Life Cycles in Dutch Manufacturing*
}

\author{
Machiel van Dijk
}

* This research has been executed at the Center for Research of economic Micro-data $(\mathrm{Ce} R \mathrm{eM})$ of Statistics Netherlands. The views expressed in this paper are those of the author and do not necessarily reflect the policies of Statistics Netherlands. 


\begin{abstract}
Theories and models on product life cycles explain and depict the evolution of an industry's structural and dynamic properties over its lifetime. Hence, empirically observed intersectoral differences may stem from different evolutionary stages that industries occupy. The aim of this paper is to find empirical evidence for this explanation. By using a model on industrial evolution by Klepper (1996), and by exploring a firm-level dataset on the Dutch manufacturing sector, this paper will show that industries in different stages show significantly different regularities. Furthermore, it will be shown that to a considerable extent, the observed regularities are in line with Klepper's model. However, no evidence was found for Klepper's hypothesis that differences in industrial regularities can be explained by dynamic increasing returns from technological change.
\end{abstract}




\section{Introduction}

Previous empirical studies on industrial dynamics ${ }^{1}$ have shown the existence of significant differences between industries with regard to their structural and dynamic properties. By asserting that industries subsequently go through their stages of birth, growth, maturity and decline, theories on product or industrial life cycles could explain the observed differences in the following way. If each of these evolutionary stages of an industry has its own structural and dynamic properties, then crosssectional differences between industries may stem from the different evolutionary stages those industries are in. This paper aims to find empirical evidence for this explanation by posing the following question: can differences between industries be explained by the different evolutionary stages they occupy?

In order to answer this question, this paper will test a number of hypotheses derived from a model on industry evolution, offered by Steven Klepper in the American Economic Review of June 1996. This model was selected, since it is one of the most recent and advanced model on industrial life cycles, capturing issues like the firms' innovative efforts, scale economies, and the shift over time from product innovations to process innovations. Furthermore, this model allows for the derivation of a number of testable hypotheses.

The most important feature of this model is the dynamic increasing returns from technological change. The model emphasizes differences in firm innovative capabilities and the importance of firm size in appropriating the returns from innovation to explain regularities concerning how entry, exit, market structure, and innovation vary from the birth of technologically progressive industries through maturity. Unfortunately, the time span of the data used in this paper does not allow for studying the full evolution of the industries in the sample. Therefore, this paper does not directly test the model, but uses it instead as a conceptual tool to answer the following questions: (1) Do industries in different stages show different regularities? (2) Are these observed regularities in line with the regularities predicted by Klepper's model? (3) Can the observed differences be explained by dynamic increasing returns from technological change?

The structure of the paper is as follows. In the next section a short overview of previous and related work in the field of industrial evolution and the product life cycle will be given. In section 3 a summary of Klepper's model is presented. The firm level data used for testing the hypotheses are described in section 4, together with the restrictions they impose on deriving and testing the hypotheses. In section 5 , ten hypotheses are derived from a selection of the propositions provided by Klepper (1996). These hypotheses will be tested and discussed in section 6 . In section 7, the sample will be split up in two groups of industries, for which the hypotheses will be tested again to examine whether better results can be obtained for one of the subgroups. Section 8 concludes this paper.

\footnotetext{
${ }^{1}$ See, for instance, Baldwin (1995), Acs and Audretsch (1991), Dosi (1988).
} 


\section{The product life cycle}

The concept of the product life cycle is nowadays well established in economics. Most successful products exhibit a life cycle which basically consists of four subsequent stages: introduction, expansion, consolidation, and contraction. When the product is introduced, sales are low and prices are high, but in the expanding stage sales increase rapidly and prices fall significantly. Both trends level off in the consolidating stage, after which sales start to fall during the contracting stage; for prices the trend is less clear during this stage. These regularities in itself may have important implications for firms marketing their products ${ }^{2}$, but from the perspective of industrial organization, the most interesting aspects of the product life cycle are the co-evolving structural and dynamic properties of the industry. For instance, as Schumpeter (1939) already observed, after the introduction of a major product innovation, a strong "band-wagon" effect often appears, followed by the entry of many new firms into the rapidly expanding sectors, attracted by the high profits associated with innovations. However, the entry of new firms leads to an erosion of profit rates, and as the industry matures and its product becomes standardized, a shift to cost-saving innovations occurs and the exploitation of scale economies becomes more important, leading to a reduction in the number of firms in the industry.

Textbook models of perfect and monopolistic competition are not able to reproduce these regularities. The main reason for this is that such models are static, whereas the product life cycle is essentially a dynamic process. But even applying comparative static analysis could not show the patterns described by the product life cycle framework. Suppose the product life cycle would be simulated in a model of perfect competition by an exogenously shifting demand curve. In such models the relationship between demand and the number of firms would always be linear: ceteris paribus, the change in the number of firms is always equal to the total change in demand divided by the cost minimizing size of the representative firm. In the framework of the product life cycle, however, this relationship is not linear at all. There can even be an increase in demand and a simultaneous reduction in the number of firms in the industry. This last regularity can be reproduced only by an (again) exogenously changing production function such that the average cost minimizing size of the representative firm increases. Still, this would not reflect the observed gradual standardization of the industry's product over its life cycle, simply because in models of perfect competition the products are assumed to be homogeneous. Models of monopolistic competition could solve for this, by imposing a decreasing elasticity of the firm's individual demand curve. But then again the adjustment needed to reproduce the different regularities of the different stages of the product life cycle would have to be imposed on the model.

In conclusion, static models of industrial organization can only be artificially used for studying the different regularities of the different evolutionary stages of an industry by exogenously changing the relevant parameters of the model. But these models cannot explain why these parameters change over the life cycle of an industry. Therefore, a different approach is needed to model and analyze the relationships between the

\footnotetext{
${ }^{2}$ See e.g., Levitt (1965), or Hayes and Wheelwright (1979a and 1979b).
} 
product life cycle, the co-evolving nature of technological change and their impact on industrial dynamics.

The first important contributions in studying these relationships have been provided by William Abernathy and James Utterback ${ }^{3}$, by introducing the notion of a dominant design. In their view, new industries are initially characterized by uncertainty about the product's technology and the user preferences. In this stage market shares often change rapidly between successful innovators and less efficient rivals, with firms mainly competing on product innovations. However, as both producers and consumers gradually select the desired features of the product, the opportunities for improving the product decrease. At this stage a "dominant design" has emerged, and a shake-out of firms not able to efficiently produce this dominant design will take place. At the same time surviving firms gradually shift their attention from product improvements to means of producing more efficiently, by investing in capital intensive production methods. This increases the minimum efficient size of firms in the industry, which forces firms below this size to exit as well. Eventually, the industry consolidates as the opportunities for improving the production process are depleted. Hence, process innovations occur less frequently and become more incremental, causing market shares to stabilize.

Other important contributions can be found in Gort and Klepper (1982), and Klepper and Graddy (1990). Gort and Klepper construct a theory of the evolution of a new industry to explain the history of the diffusion of 46 products. They distinguish five evolutionary stages with respect to the number of producers in a prototypical new industry. The commercial introduction of a new product marks the beginning of stage I. Stage II is defined as the period of sharp increase in the number of producers, whereas in stage III the number of entrants more or less balances the number of exiting firms. Stage IV then is the period negative net entry, and finally stage $V$ is the second period of approximately zero net entry. However, Gort and Klepper apply their following model only to stages II, III, and IV.

By definition, in every period the expected number of entrants is equal to the probability of entry of each potential entrant, multiplied by the number of potential entrants. The probability of entry depends on information on new product technology, including the potential rewards of entry. The information stems from two sources: (1) non-transferable information emanating from experience in production by existing firms, and (2) information emanating from sources outside the set of current producers. The first type of information has a negative effect on the probability of entry, since it provides an advantage of incumbents over entrants and hence operates as an entry barrier. Because the second type of information reduces the value of accumulated experience of incumbents, it has a positive effect on entry. In the early stages of the product life cycle, most innovations are based on the second type of technological information, whereas at later stages the innovations emanate more from the accumulated stock of experience of existing firms.

Therefore, entry rates are high in the early stage of an industry, when the number of firms is relatively low and, consequently, profits are high. But as the industry

\footnotetext{
${ }^{3}$ See, for instance, Utterback and Abernathy (1975) and Abernathy and Utterback (1978).
} 
matures, three forces reduce the entry of firms: (1) the accumulation of experience by existing firms, (2) the decrease in profit rates resulting from an increase in the number of producers, and (3) a gradual reduction in the population of potential entrants that have not yet entered the market. Eventually a point of zero net entry is reached, but as the above mentioned process continues, entry rates are still falling and exit rates will rise sharply, because the increasing competition compresses profit margins and forces less efficient firms to leave the market. Gort and Klepper (1982) find substantial support for their hypotheses in analyzing the 46 product histories. However, as they state in their conclusion: "We view many of these inferences as only first steps toward developing a theory of the evolution of industries."

In this respect, Klepper and Graddy (1990) could be seen as a second step in developing such a theory. After reanalyzing the data set assembled by Gort and Klepper, they establish three evolutionary stages, again with respect to the number of firms in a new industry: first it grows, then declines sharply, and finally it levels off. ${ }^{4}$ Based on this and other inferences about output and prices, Klepper and Graddy construct a model which aims at explaining the observed regularities. In comparison with Gort and Klepper (1982), the model by Klepper and Graddy focuses more on individual firms. They assume that the limited number of potential entrants differ in the average costs and product quality, and that cost reductions only occur immediately after entry by means of imitating more efficient rivals. All firms in the industry change their capacity in each period at a rate that is determined by their average cost relative to the prices.

Including some other assumptions, Klepper and Graddy (1990) show that their model is "capable of explaining the fall in price, the rise in output, and the eventual levelling off of both that characterizes the evolution of new industries." According to the model, in the early stage of a new industry, when prices are relatively high, the number of firms increases because all firms are profitable, and consequently no prior entrants exit the industry. But as the price decreases, firms with high cost levels will eventually make losses and therefore exit the industry. At some point, the price will attain a level at which profitable entry is no longer possible, causing entry to cease. With exit still continuing, the number of firms in the industry drops significantly, until eventually price levels off, which stabilizes the number of firms.

Although the model by Klepper and Graddy is capable of reproducing many empirical regularities concerning the evolution of new industries, the authors admit that their model is highly simplified, excluding factors as innovation by incumbents, scale economies, and strategic behaviour. Also the gradual shift over time from product innovations to process innovations, as observed by for instance Schumpeter (1939), is absent in their model. As mentioned in the introduction, the model by Klepper (1996) does include many of these issues. Furthermore, it allows for the derivation of a number of testable hypotheses, as will be shown in the next sections. For these reasons, Klepper (1996) provides the most appropriate model given the aim of this paper: to study empirically the relation between the evolutionary stages of industries and their structural and dynamic properties.

\footnotetext{
${ }^{4}$ Hence, these stages resemble respectively stages II, IV and V of Gort and Klepper (1982).
} 


\section{The model}

This section highlights the most important features of the model offered by Klepper (1996). The basic idea of the model is to depict the evolution of a new, technologically progressive industry. In this model, all the decisions of the firms are made to maximize current expected profits. For firm $i$ in period $t$, the expected profit $E\left(\Pi_{\mathrm{it}}\right)$ can be expressed as:

$$
\begin{aligned}
E\left(\Pi_{\mathrm{it}}\right)= & {\left[s_{\mathrm{i}}+g\left(\mathrm{rd}_{\mathrm{it}}\right)\right] G-F-\mathrm{rd}_{\mathrm{it}}+} \\
& {\left[Q_{\mathrm{it}-1}\left(Q_{\mathrm{t}} / Q_{\mathrm{t}-1}\right)+\Delta q_{\mathrm{it}}\right] *\left[p_{\mathrm{t}}-c+l\left(\mathrm{rc}_{\mathrm{it}}\right)\right]-\mathrm{rc}_{\mathrm{it}}-m\left(\Delta q_{\mathrm{it}}\right) }
\end{aligned}
$$

In the first part of this expression, $\left[s_{\mathrm{i}}+g\left(\mathrm{rd}_{\mathrm{it}}\right)\right]$ is the probability of firm $i$ developing a product innovation. This probability is determined by two factors. The first one is the firm's innovative expertise $s_{\mathrm{i}}$, with which it is randomly endowed at its birth and which remains constant over time ${ }^{5}$. The second factor is the firm's spending on product $\mathrm{R} \& \mathrm{D}$, i.e., $\mathrm{rd}_{\mathrm{it}}$. The function $g\left(\mathrm{rd}_{\mathrm{it}}\right)$ reflects the opportunities for product innovation. The following conditions apply:

(i) $\quad g^{\prime}\left(\mathrm{rd}_{\mathrm{it}}\right)>0, \forall \mathrm{rd}_{\mathrm{it}} \geq 0$

(ii) $\quad g^{\prime \prime}\left(\mathrm{rd}_{\mathrm{it}}\right)<0, \forall \mathrm{rd}_{\mathrm{it}} \geq 0$

(iii) $\quad g^{\prime}(0) G>1$

(iv) $\forall t, \exists i$ s.t. $s_{\mathrm{i}}=s_{\max }$

(v) $\quad s_{\mathrm{i}}+g\left(\mathrm{rd}_{\mathrm{it}}\right) \leq 1$

$G$ denotes the one-period gross monopoly profit from offering a distinct product variant achieved by a successful product innovation. The innovators sells the distinctive variant of the product at a higher price than the price of the standard product, but the monopoly profits are only made for one period, because other firms monitor all the innovations at some fixed $\operatorname{costs}^{6} F$ and subsequently imitate the innovation without any additional costs. After one period, all product innovations are copied and incorporated in the standard product. It is assumed that $F>\left[s_{\mathrm{i}}+g\left(\mathrm{rd}_{\mathrm{it}}\right)\right] G$ - $\mathrm{rd}_{\mathrm{it}}$ for all $\mathrm{rd}_{\mathrm{it}}$. Hence, all firms must produce the standard product in order to have nonnegative profits. Condition (iii) ensures that $\mathrm{rd}_{\mathrm{it}}>0$ for all $i, t$.

The second part of expression (1) denotes the firm's net profit from producing the standard product after subtracting its spending on process $\mathrm{R} \& \mathrm{D}, \mathrm{rc}_{\mathrm{it}}$, and the costs of adjusting its output, $m\left(\Delta q_{\mathrm{it}}\right) . Q_{\mathrm{t}}$, the total quantity demanded, expands over time as the price of the standard product, $p_{\mathrm{t}}$, falls over time. A key assumption is that incumbents can maintain their market share at no additional costs. Hence, they experience a rise in their sales from $Q_{\mathrm{it}-1}$ in period $t-1$ to $Q_{\mathrm{it}-1}\left(Q_{\mathrm{t}} / Q_{\mathrm{t}-1}\right)$ in period $t$, where $Q_{t} / Q_{\mathrm{t}-1}$ is the growth in total quantity demanded. If it wants to increase its

\footnotetext{
${ }^{5}$ The cumulative distribution function $H(s)$, from which the innovation expertise $s_{\mathrm{i}}$ is drawn, is the same for the potential entrants in each period.

${ }^{6}$ According to Klepper (1996), these monitoring costs $F$ have to be incurred by a firm "in order to be able to imitate costlessly the innovations of its rivals, which is required to market a distinctive product variant and also the standard product..."
} 
output further (i.e., increasing its market share), it must incur an adjustment cost of $m$ $\left(\Delta q_{\text {it }}\right)$, where $\Delta q_{\text {it }}$ is the expansion in its output above $Q_{\mathrm{it}-1}\left(Q_{\mathrm{t}} / Q_{\mathrm{t}-1}\right)$. Increasing market share is however assumed to be subject to increasing marginal adjustment costs.

The function $l\left(\mathrm{rc}_{\mathrm{it}}\right)$, reflecting the opportunities for process $\mathrm{R} \& \mathrm{D}$, is assumed to asymptotically approach an upper bound as $\mathrm{rc}_{\mathrm{it}}$ increases. Furthermore it reflects diminishing returns. Hence, $l$ ' $\left(\mathrm{rc}_{\mathrm{it}}\right)>0$ and $l^{\prime \prime}\left(\mathrm{rc}_{\mathrm{it}}\right)<0$ for all $\mathrm{rc}_{\mathrm{it}} \geq 0$. Because of the assumption that $l^{\prime}(0) Q_{\min }>1$, where $Q_{\min }$ is the smallest level of output ever produced by any firm, $\mathrm{rc}_{\mathrm{it}}>0$ for all $i, t$. Finally, the average cost of producing the standard product ${ }^{7}$ is assumed to be independent of $Q_{\text {it }}$ and equal to $c-l\left(\mathrm{rc}_{\mathrm{it}}\right)$. Thus if no firm spends money on process $R \& D$, the average cost of producing the standard product is equal to $c$, and it is the same for every firm.

If the expected profits are negative, incumbents will exit the industry. Entrants will only enter if the expected profits are positive. In each period $t$ there is a limited number of potential entrants $K_{t}$. For entrants, expression (1) applies as well, with $Q_{\mathrm{it}-1}$ equal to zero. It is assumed that all firms are atomistic and price takers, and the market is cleared in every period. In every period firms decide on how much will be spent on product $R \& D$, process $R \& D$, and the expansion in market share to maximize current expected profits.

The main implication of the model is that the industry will eventually evolve to an oligopoly. The earliest successful entrants engage in $R \& D$ and start growing. This increases their returns from $R \& D$, because the output in which they can embody their innovations rises. Initially, i.e., in the expanding stage, firms enter, but at some point the price is driven down to a level at which (profitable) entry is no longer possible. Exit still continues, as for some firms the price falls below their average costs. Hence the number of firms declines, contributing to a shake-out. Eventually, both industrial sales and the number of firms level off. It is in this consolidating stage that the oligopoly emerges.

In Klepper (1996), these results are formalized in a number of propositions. As mentioned in the introduction, this paper will test some hypotheses which are based on Klepper's propositions. However, since the data used in this paper impose some restrictions in selecting and testing the hypotheses, the features of the dataset are first discussed in the next section. The presentation of the selected propositions and hypotheses is postponed until section 5 .

\footnotetext{
${ }^{7}$ Here, Klepper follows Flaherty (1980): average cost in period $t$ is a function of only process R\&D in period $t$. However, as Klepper argues: "If all process improvements were assumed to be costlessly imitated one period after they were introduced, firm differences in average costs would still be a function of only differences in contemporaneous firm spending on process $R \& D$.... This change would not affect the model. Even if cost differences were allowed to cumulate, it would only reinforce the advantages of the largest firms."
} 


\section{The data}

This section describes the Statistics Netherlands manufacturing database that is used in this paper. Some general information about the database (e.g., the period it captures, the number of firms, etc.) will be provided, but attention will also be paid to the specific limitations of it, especially with regard to its truncation.

The dataset captures all firms with more than twenty employees (working 15 hours or more weekly) that have been active in the Dutch manufacturing sector between 1978 and 1992. Furthermore, it contains 4,415 observations of firms employing less than twenty employees. Some of these observations represent firms that are initially or ultimately below the threshold of twenty employees, but also about 600 firms that stay below twenty employees throughout their presence are included.

In total, there are 84,248 observations representing 10,011 firms, of which 2838 firms are present throughout the whole period. These continuing firms on average capture 57.3 and $55.5 \%$ of respectively total manufacturing employment and sales. The remaining firms are only temporarily present in the dataset; on average they are observed for 5.5 years. Although these firms enter and exit the database, defining them as entrants and exiters is not appropriate in most of the cases. For the period from 1986 and onwards, Statistics Netherlands provides information about the specific reasons why firms enter or exit the database. The majority of the entering and exiting firms appear or disappear because they cross the threshold of twenty employees at which they are or are not recorded in the dataset. On average, only $8.9 \%$ and $21.1 \%$ of the firms entering and exiting the database are respectively greenfield entrants and closedown exiters. ${ }^{8}$

For each firm, the following variables are available on an annual basis:

-Class of manufacturing: All firms are allocated to a 4-digit industry, according to the standard industrial classification of Statistics

Netherlands (as of 1974).

-Number of employees: $\quad$ The number of employees working more than 15 hours weekly, employed by the end of September.

-Industrial sales: $\quad$ This is including exportrestitutions.

-Total production value: This is equal to the sum of industrial sales, activated costs (i.e., costs made for the internal production of capital goods for own use), net changes in the inventory of final products and of work in progress.

-Total consumption value: This is equal to the sum of industrial purchases, changes in the stock of raw materials, energy charges and other costs.

-Value added: $\quad$ This is equal to the total production value minus the total consumption value.

-Indirect taxes: $\quad$ Indirect taxes (excluding value added tax) and levies less operating subsidies received.

\footnotetext{
${ }^{8}$ Unfortunately, the data do not allow to identify these greenfield entrants and closedown exiters.
} 
-Labour costs:

Total sum of gross salaries, including social security payments by the firm.

-Gross result:

This is equal to value added minus labour costs and indirect taxes and levies.

Furthermore, for most observations we have information about the gross investments in fixed assets. In total, 15,564 observations (out of 84,248) have missing values on this variable, however.

Given the characteristics of the dataset used for this paper, a number of problems arise. The major problem of course is that the entire evolutionary history of each industry cannot be observed, i.e., the origin of the industries occur before the first year of observation. Therefore it cannot be tested whether the industries evolve according to the pattern predicted by Klepper's model. In stead, an attempt will be made to locate the industries in the sample in terms of the evolutionary stage that they occupy in Klepper's framework. This is facilitated by the relatively long period over which the firms are observed in the dataset. Hence, this paper will investigate to what extent industries in different stages show different regularities, and test whether these differences are consistent with the model. ${ }^{9}$

A second issue related to the data is the definition of an industry. In Klepper (1996), an industry consists mainly of firms producing the same standard product and of some firms temporarily producing a distinctive variant of the standard product. Although the industry classification of the Statistics Netherlands dataset is designed to obtain high levels of homogeneity with respect to the products and the technologies used within an industry, there might still be a number of industries left that are less homogeneous than the industries in Klepper's model. Since the identification of those industries is to some extent an arbitrary exercise, and in order to keep the sample large, no attempt will be made to identify or exclude those industries.

For the same reasons, no attempt is made to exclude industries which are not technologically progressive. Klepper (1996) defines technologically progressive products as "products with rich opportunities for both product and process innovation". Although to some extent manufactured goods always have opportunities for innovating either the product itself or the way it is produced, it is not likely that all industries in the sample used in this paper fulfil the criterion of technologically progressiveness. However, it has to be stressed again that this paper does not directly test Klepper's model. As mentioned in the introduction, the model is mainly used as a conceptual tool to examine whether differences between industries can be explained by the different evolutionary stages they occupy. But in addition to this, the inclusion of the industries which are not technologically progressive could also allow for an identification of features of Klepper's model that are applicable to manufacturing industries in general, i.e., without reference to their technological progressiveness.

Two variables are used to determine in which stage an industry is: the growth rate of the total number of firms (GRTF) and the growth rate of the sum of their total

\footnotetext{
${ }^{9}$ This methodology is very similar to Audretsch (1987).
} 
industrial real sales (GRTSLS), for the period 1978 to 1992. Next, a standard t-test was applied to determine whether each of these growth rates was significantly different from zero. Hence, for every industry, the GRTF and the GRTSLS were divided by their corresponding standard errors of the means of GRTF and GRTSLS for the whole set of industries, in order to calculate the t-statistic. This value of the tstatistic was then used to determine whether an industry experienced a significant growth (or decline) in its total number of firms and in its total industrial sales. For instance, if for an industry the value of the t-statistic of GRTF was less then -2 , the growth rate of the total number of firms is significantly less then zero $(\mathrm{GRTF}<<0)$ at the $5 \%$ significance level. ${ }^{10}$ The following table explains how each industry is classified into the stage of its evolution. Between brackets the number of industries in each cell is listed.

\begin{tabular}{|c|c|c|c|}
\hline & GRTF $>>0$ & GRTF $\approx 0$ & GRTF $<<0$ \\
\hline $\begin{array}{c}\text { GRTSLS } \\
>>0\end{array}$ & Expanding & Expanding & Shake-out \\
$(36)$ & $(15)$ & $(16)$ \\
\hline $\begin{array}{c}\text { GRTSLS } \\
\approx 0\end{array}$ & Other & Consolidating & Shake-out \\
\hline $\begin{array}{c}\text { GRTSLS } \\
<<0\end{array}$ & Other & $(6)$ & $(12)$ \\
\hline
\end{tabular}

Given this classification, we have 51 industries in the expansion phase, 28 industries experiencing a shake-out, 6 industries are consolidating, 17 industries are contracting, and 4 industries are in the "other" class. This last group and the group of consolidating industries will be left out of the analysis, because of the small sample sizes. The high standard errors of the means of most of the variables impede the detection of significant differences. Hence, the focus will only be on expanding industries, industries experiencing a shake-out, and contracting industries. In appendix 1 all industries are listed and grouped according to their evolutionary stage.

No reference is made to the absolute age of the industries, only the change in the number of firms and the change in total sales determine which stage an industry occupies in Klepper's framework. So it might happen that industries which have been existing for many decades are classified as expanding. Although expanding industries are usually associated with young industries, the classification of some older industries as "expanding" is not necessarily incorrect: for administrative reasons, new products (and their producers) could be allocated to an existing, technologically related industry.

Since the industries might show different structural properties, especially with respect to (potential) entry barriers, dividing the industries in three subgroups could create some bias. For instance, if by coincidence the group of expanding industries contains a large number of industries with high entry barriers, then the results of testing a hypothesis for differences between the group of industries with respect to entry rates will be unreliable. Therefore the three groups were compared with respect to the means of capital intensity, approximated by the ratio of investments to sales, and median firm size. Because the means of these variables did not differ significantly

\footnotetext{
${ }^{10}$ Given the sample size of 106 , the actual significance level is even slightly lower than $5 \%$.
} 
between the three groups, there is less reason to believe that the proposed division leads to a bias with respect to different structural properties of the groups of industries.

\section{The hypotheses}

Klepper (1996) derives ten propositions from his model. Only four of these propositions are given below, because the other six are either related to issues for which data is unavailable, or they do not allow to derive additional, distinct hypotheses. Although all propositions are already proven in Klepper (1996), still the proofs are given here, since the derivation of a number of hypotheses are directly based on them. Subsequently, for each proposition, the possibilities of testing them will be considered, given the characteristics of the dataset of Statistics Netherlands.

PROPOSITION I: Initially the number of entrants may rise or decline, but eventually it will decline to zero.

To prove this proposition, first the first-order conditions for maximizing expected current profits are derived by differentiating (1) with respect to $\mathrm{rd}_{\mathrm{it}}, \mathrm{rc}_{\mathrm{it}}$, and $\Delta q_{\mathrm{it}}$ :

$$
\begin{aligned}
& g^{\prime}\left(\mathrm{rd}_{\mathrm{it}}{ }^{*}\right) G=1 \\
& {\left[Q_{\mathrm{it}-1}\left(Q_{\mathrm{t}} / Q_{\mathrm{t}-1}\right)+\Delta q_{\mathrm{it}}{ }^{*}\right] l^{\prime}\left(\mathrm{rc}_{\mathrm{it}}{ }^{*}\right)=1} \\
& m^{\prime}\left(\Delta q_{\mathrm{it}}{ }^{*}\right)=p_{\mathrm{t}}-c+l\left(\mathrm{rc}_{\mathrm{it}}{ }^{*}\right),
\end{aligned}
$$

where an asterisk denotes optimal values. Since it is assumed that $F>\left[s_{\mathrm{i}}+g\left(\mathrm{rd}_{\mathrm{it}}\right)\right] G$ $-\mathrm{rd}_{\mathrm{it}}$ for all $\mathrm{rd}_{\mathrm{it}}$, a necessary condition for nonnegative expected profits is:

$$
p_{\mathrm{t}}-c+l\left(\mathrm{rc}_{\mathrm{it}}^{*}\right)>0
$$

Klepper's assumptions assure that $\Delta q_{\mathrm{it}}{ }^{*}>0$, hence all firms that remain in the market in period $t$ increase their market share. Another implication is that the firm's incremental profit earned from product $R \& D$ remains constants over time, since $\mathrm{rd}_{\mathrm{it}}{ }^{*}$ is defined by (2) and is the same for all firms. Let $V E_{\mathrm{it}}{ }^{*}=\Delta q_{\mathrm{it}}{ }^{*}\left[p_{\mathrm{t}}-c+l\left(\mathrm{rc}_{\mathrm{it}}{ }^{*}\right)\right]-\mathrm{rc}_{\mathrm{it}}{ }^{*}-$ $m\left(\Delta q_{\text {it }}{ }^{*}\right)$ denote the entrant's incremental profit earned from the standard product. Differentiating $V E_{\mathrm{it}}{ }^{*}$ with respect to $p_{\mathrm{t}}$ yields

$$
d V E_{\mathrm{it}}{ }^{*} / d p_{\mathrm{t}}=\partial V E_{\mathrm{it}}{ }^{*} / \partial p_{\mathrm{t}}=\Delta q_{\mathrm{it}}{ }^{*}
$$

Given that $\Delta q_{\text {it }}{ }^{*}>0$ and that $p_{\mathrm{t}}$ falls over time, $V E_{\mathrm{it}}{ }^{*}$ must fall over time as well. Thus the marginal entrant must earn greater incremental profit from product innovation over time, which can only be achieved by a higher innovative expertise $s_{\mathrm{i}}$. Hence, over time the minimum innovative expertise required for entry must rise. As long as this minimum level is lower than or equal to $s_{\max }$, then $E\left(\Pi_{\mathrm{it}}{ }^{*}\right) \geq 0$ for potential entrants with $s_{\max }$. In that case $E\left(\Pi_{\mathrm{it}}{ }^{*}\right)>0$ for all prior entrants with $s_{\max }$, because they spent more on process $R \& D$ and have lower average cost therefore. This can be shown by rewriting (3) as $Q_{\mathrm{it}} l^{\prime}\left(\mathrm{rc}_{\mathrm{it}}{ }^{*}\right)=1$, and since $Q_{\mathrm{it}}>Q_{\mathrm{it}-1}$, and $l^{\prime \prime}\left(\mathrm{rc}_{\mathrm{it}}\right)<0$, it 
follows that $\mathrm{rc}_{\mathrm{it}}>\mathrm{rc}_{\mathrm{it}-1}$. As a consequence, no incumbent firm with $s_{\max }$ will exit the industry. In fact, they will want to expand their market share, but because this cannot happen indefinitely, some incumbents will have to exit the industry. This requires a decrease in $p_{\mathrm{t}}$ such that $E\left(\Pi_{\mathrm{it}}{ }^{*}\right)<0$ for some incumbents with $s_{\max }$. After that point, potential entrants even with $s_{\max }$ will be unable to earn positive profits, and no further entry will occur.

Since the majority of the firms appearing in the Statistics Netherlands dataset are not entrants, but just continuing firms crossing the observation threshold of twenty employees, Klepper's first proposition cannot be tested directly. We can, however, look at the differences between the stages with regard to the proportion of firms entering the sizeclass of more than twenty employees. If the advantage of incumbents over entrants grows over time, it should become more difficult for small firms to (1) grow and pass the observation threshold, (2) to stay above the threshold, and (3) to obtain a significant market share in the industry. This leads to the first three hypotheses.

I.1: The entryrates in expanding industries are higher than in industries experiencing a shake-out.

I.2: Firms entering expanding industries have higher survival rates than firms entering shake-out industries.

I.3: The collective share of all entrants at the end of the observation period is higher in expanding industries than in industries experiencing a shake-out.

Given that $\Delta q_{\mathrm{it}}{ }^{*}>0$ :

I.4: Incumbents have a higher market share in 1992 than in 1978.

Since the model predicts that over time incumbents achieve an increasing cost advantage over entrants, we can derive a fifth hypothesis:

I.5: Incumbents are more productive and profitable than entrants, and the gaps between continuing firms and entrants are higher in shake-out industries than in expanding industries.

To summarize these five hypotheses: testing I.1 to I.3 should reveal the growing advantage of incumbents over entrants, whereas testing I.5 should indicate whether this growing advantage is caused by superiority in production. Hypothesis I.4 follows directly from the model's assumption of profit maximization.

PROPOSITION II: Initially, the number of firms may rise over time, but eventually it will decline steadily.

In proving proposition $\mathrm{I}$, it was shown that $p_{\mathrm{t}}$ must fall over time by a sufficient amount to cause some firms to exit in every period. Secondly, it was also shown that after some time entry ceases. Hence, eventually the number of firms will decline. Since the change in the number of firms is used for classifying the industries into the 
stages of the life cycle, this proposition cannot be tested. However, Klepper's following intuitive proof of this proposition allows for another hypothesis.

Klepper (1996): “Intuitively, over time price falls, the more innovative incumbents expand, and the less innovative incumbents exit and are replaced by more innovative, smaller entrants. This can result in a rise in the number of producers. However, as incumbents continue to grow their advantage eventually becomes insurmountable and entry ceases. Exit continues, though, as the largest firms with the greatest innovative expertise expand their market shares and push the less fit firms out of the market. Consequently, eventually the number of firms declines over time."

II.1: In expanding industries, a certain number of incumbents are replaced by a larger number of smaller entrants ${ }^{11}$. In industries experiencing a shake-out, the largest firms expand their market shares at the expense of smaller firms.

PROPOSITION III: As each firm grows large, eventually the change in its market share, $\Delta q_{\mathrm{it}} / Q_{\mathrm{t}}$ will decline over time.

If $\Delta q_{\text {it }}$ declines in time, $\Delta q_{\text {it }} / Q_{\mathrm{t}}$ will decline, because $Q_{\mathrm{t}}$ is nondecreasing over time. As expression (4) indicates, $\Delta q_{\mathrm{it}}$ is based on $p_{\mathrm{t}}-c+l\left(\mathrm{rc}_{\mathrm{it}}\right)$. Since $\mathrm{rc}_{\mathrm{it}}$ grows in time, $l$ $\left(\mathrm{rc}_{\mathrm{it}}\right)$ will grow as well, but eventually it will approach its upper bound. However, $p_{\mathrm{t}}$ falls over time, and therefore $p_{\mathrm{t}}-c+l\left(\mathrm{rc}_{\mathrm{it}}\right)$, the profit margin on the standard product, decreases as well. Consequently, $\Delta q_{\text {it }}$ declines in time.

The prediction that the continuing firm's growth in market share declines over time can easily be tested with the available data. It is not so easy to test whether the profit margin on the standard product decreases. In the model, the profit margin is defined as price minus average cost of production. The latter are negatively dependent on the amount spent on process R\&D. Since there is no data on any of these variables, the profit rate (total profits before taxes over total sales) is taken as a proxy for the profit margin. This leads to the following hypotheses.

III.1: The growth of continuing firms' market shares is positively related to their profit rates.

III.2: Profit rates are higher in expanding industries than in industries experiencing a shake-out.

III.3: The growth of market shares of continuing firms is higher in expanding industries than in industries experiencing a shake-out.

Klepper's next five propositions are all related to issues like the number of product innovations, and the amount spent on product and process R\&D. As mentioned before, the absence of data on these variables impedes the derivation of testable

\footnotetext{
${ }^{11}$ The emphasis here is of course not on the entrants being smaller than the incumbents, because this will obviously be accepted given that entrants are typically small firms. What will actually be tested here is that some incumbent firms exit the expanding industry, whereas at the same time new firms enter.
} 
hypotheses. ${ }^{12}$ Therefore, these propositions are skipped, which leads us to the fourth proposition considered here (proposition 9 in Klepper's article).

PROPOSITION IV: For each period, firm average cost varies inversely with firm output.

Klepper (1996): "Since $r c_{i t}$ varies directly with $Q_{i t}$ and $l$ ' $\left(r c_{i t}\right)>0$ for all $r c_{i t}$, it follows directly that c - l $\left(r c_{i t}\right)$ varies inversely with $Q_{i t}$."

This proposition implies that in each period small firms are less productive and profitable than large firms, basically because of scale economies in process R\&D. Hence the following hypothesis can be derived.

IV.1: For each period, large firms are more productive ${ }^{13}$ and profitable than small firms.

\section{The results}

In this section, the ten hypotheses will be tested. For each hypothesis, the specific variables used for testing are defined. Subsequently, the results of the test will be reported, together with a short discussion on the acceptability of the hypothesis.

Although the model does not deal with the evolution of industries after consolidation, since the total quantity demanded expands over time, it might be interesting to see to what extent the group of contracting industries differ from the other groups. Therefore, for each hypothesis the values of the specific variables for the contracting industries are listed as well.

Hypothesis I.1: The entryrates in expanding industries are higher than in industries experiencing a shake-out.

Here, an entrant is defined as a firm appearing in the dataset for the first time. For each industry, the mean of annual gross entry rates defined as the number of entrants in a certain year divided by the number of continuing firms present at the beginning of the year, is calculated (ENTRYRT). In the second column of the table below, the mean and its standard error are listed for each stage. The rest of the table shows the output of a $t$-test to test the hypothesis that the true means of the different groups of industries are the same. Because the $t$-statistic can only be computed if the variances of the two populations are equal, first an $F$-test is performed to test the hypothesis that the sample variances are equal. The value of the $F$-statistic (the highest sample variance divided by the lowest sample variance) is listed in the third and fifth column. Between brackets the corresponding $p$-values can be found. This $p$-value indicates the significance level at which the observed $F$ value is not significant (given the degrees

\footnotetext{
${ }^{12}$ Audretsch (1987) however found significant differences between industries in different evolutionary stages with respect to R\&D and skill intensity "consistent with the assumptions of the empirical literature."

${ }^{13}$ In terms of value added per employee.
} 
of freedom). Hence, a $p$-value of 0.05 implies that $F$ is significant at the 5 percent level.

When this $p$-value is higher than 0.05 , the hypothesis that the sample variances are equal is accepted. The $t$-statistic (of the hypothesis that the true means of the different groups of industries are the same) is then calculated on the basis of a pooled-variance estimate. If the $p$-value is lower than 0.05 , the hypothesis that the sample variances are equal is rejected, implying that the $t$-statistic cannot be computed for the difference in sample means. In that case, an approximation of $t$ is computed, based on a separate variance estimate. In column four and six the values of the $t$-statistics are listed. The corresponding $p$-values can be found between brackets, indicating the probability of the occurrence of a value larger than $t$. If the p-value is less than 0.05 , we reject the hypothesis that the true means of the groups of industries under consideration are the same. An asterisk indicates that $t$ is approximated.

\begin{tabular}{|c|c|c|c|c|c|}
\hline \multicolumn{2}{|c|}{ ENTRYRT $(\%)$} & \multicolumn{2}{c|}{ vs. Shake-out } & \multicolumn{2}{c|}{ vs. Contraction } \\
\hline $\begin{array}{c}\text { Stage of } \\
\text { industry }\end{array}$ & $\begin{array}{c}\text { Mean } \\
(\text { stderr })\end{array}$ & $\begin{array}{c}\text { F-statistic } \\
(\mathrm{p} \text {-value })\end{array}$ & $\begin{array}{c}\text { T-statistic } \\
(\mathrm{p} \text {-value })\end{array}$ & $\begin{array}{c}\text { F-statistic } \\
(\mathrm{p} \text {-value })\end{array}$ & $\begin{array}{c}\text { T-statistic } \\
(\mathrm{p} \text {-value })\end{array}$ \\
\hline Expansion & $\begin{array}{c}8.72 \\
(0.72)\end{array}$ & $\begin{array}{c}5.90 \\
(<0.01)\end{array}$ & $\begin{array}{c}3.02 * \\
(<0.01)\end{array}$ & $\begin{array}{c}1.22 \\
(0.68)\end{array}$ & $\begin{array}{c}0.64 \\
(0.52)\end{array}$ \\
\hline Shake-out & 6.25 & & & 4.82 & -1.32 \\
& $(0.40)$ & & & $(<0.01)$ & $(0.20)$ \\
\hline Contraction & 7.82 & & & & \\
& $(1.12)$ & & & & \\
\hline
\end{tabular}

* approximated

As the approximated $t$-statistic indicates, the gross entryrates are indeed significantly higher in expanding industries than in industries experiencing a shake-out of firms. Hence, this hypothesis is accepted. Contracting industries show intermediate values for this variable, but with the highest standard error of the mean. The mean of the gross entryrates of contracting industries are not significantly different from expanding and shake-out industries.

Hypothesis I.2: Firms entering expanding industries have higher survival rates than firms entering shake-out industries.

The variable used here is the industrial mean of the infant mortality rates (MEANMORT). It is the proportion of entrants that exit within five years after entering the dataset. 


\begin{tabular}{|c|c|c|c|c|c|}
\hline \multicolumn{2}{|c|}{ MEANMORT } & \multicolumn{2}{c|}{ vs. Shake-out } & \multicolumn{2}{c|}{ vs. Contraction } \\
\hline $\begin{array}{c}\text { Stage of } \\
\text { industry }\end{array}$ & $\begin{array}{c}\text { Mean } \\
(\text { stderr })\end{array}$ & $\begin{array}{c}\text { F-statistic } \\
(\mathrm{p} \text {-value })\end{array}$ & $\begin{array}{c}\text { T-statistic } \\
(\mathrm{p} \text {-value })\end{array}$ & $\begin{array}{c}\text { F-statistic } \\
(\mathrm{p} \text {-value })\end{array}$ & $\begin{array}{c}\text { T-statistic } \\
(\mathrm{p} \text {-value })\end{array}$ \\
\hline Expansion & $\begin{array}{c}57.7 \\
(3.37)\end{array}$ & $\begin{array}{c}1.08 \\
(0.34)\end{array}$ & $\begin{array}{c}-3.11 \\
(<0.01)\end{array}$ & $\begin{array}{c}1.25 \\
(0.67)\end{array}$ & $\begin{array}{c}-1.28 \\
(0.20)\end{array}$ \\
\hline Shake-out & 75.6 & & & 1.16 & 1.33 \\
& $(4.58)$ & & & $(0.79)$ & $(0.19)$ \\
\hline Contraction & 66.2 & & & & \\
& $(5.27)$ & & & & \\
\hline
\end{tabular}

Again, this hypothesis is accepted. Infant mortality is significantly lower in expanding industries than in industries experiencing a shake-out. This is confirmed by the result of the $t$-test which rejects the hypothesis that the two means are the same. Contracting industries again shows an intermediate value for this variable, which is not significantly different from the other two groups of industries.

Hypothesis I.3: The collective share of all entrants at the end of the observation period is higher in expanding industries than in industries experiencing a shake-out.

For testing this hypothesis the cumulative entry penetration rate (SLENRTCM) is calculated for each industry. It is the mean of total market share in 1992 of all (surviving) firms that have entered the dataset between 1978 and 1992.

\begin{tabular}{|c|c|c|c|c|c|}
\hline \multicolumn{2}{|c|}{ SLENRTCM } & \multicolumn{2}{c|}{ vs. Shake-out } & \multicolumn{2}{c|}{ vs. Contraction } \\
\hline $\begin{array}{c}\text { Stage of } \\
\text { industry }\end{array}$ & $\begin{array}{c}\text { Mean } \\
(\text { stderr })\end{array}$ & $\begin{array}{c}\text { F-statistic } \\
(\mathrm{p} \text {-value) }\end{array}$ & $\begin{array}{c}\text { T-statistic } \\
(\mathrm{p} \text {-value })\end{array}$ & $\begin{array}{c}\text { F-statistic } \\
(\mathrm{p} \text {-value })\end{array}$ & $\begin{array}{c}\text { T-statistic } \\
(\mathrm{p} \text {-value })\end{array}$ \\
\hline Expansion & $\begin{array}{c}31.9 \\
(2.50)\end{array}$ & $\begin{array}{c}1.41 \\
(0.34)\end{array}$ & $\begin{array}{c}2.91 \\
(<0.01)\end{array}$ & $\begin{array}{c}1.84 \\
(0.18)\end{array}$ & $\begin{array}{c}2.31 \\
(0.02)\end{array}$ \\
\hline Shake-out & 20.4 & & & 1.30 & -0.16 \\
& $(2.84)$ & & & $(0.59)$ & $(0.88)$ \\
\hline Contraction & 21.1 & & & & \\
& $(3.20)$ & & & & \\
\hline
\end{tabular}

Just like the two previous hypotheses, hypothesis I.3 is accepted as well. In expanding industries, on average almost one third of the total industrial sales in 1992 is captured by firms that entered the dataset between 1978 and 1992, which is significantly higher than in shake-out industries. For contracting industries, the mean is about the same as for industries in the shake-out stage, and it is significantly lower than for the group of expanding industries.

Hypothesis I.4: Incumbents have a higher market share in 1992 than in 1978.

For each incumbent firm present in expanding or shake-out industries, the difference in market shares between 1992 and 1978 is calculated. The mean over all incumbent firms of this difference (MINCSHCH) is $-0.09 \%$ ( $\mathrm{t}$-value is equal to -1.44 ). Of all 
1962 incumbents, 907 firms had a higher market share in 1992. On average, they increased their market share by $1.2 \%$. The other 1055 firms lost on average $1.2 \%$.

Another way of testing this hypothesis is by measuring difference between the collective share of all incumbents in 1992 and 1978. The mean over all industries of this difference (DIFINCSH) is $-2.3 \%$, but with a t-value of -1.14 it is not significantly different from zero. Hence, there is no support for this hypothesis.

Hypothesis I.5: Incumbents are more productive and profitable than entrants, and the gaps between continuing firms and entrants are higher in shake-out industries than in expanding industries.

Incumbents are defined as firms present in the same industry throughout the whole period. Entrants are defined as firms not present in 1978, but extant in 1992. Productivity is measured by the real value added per employee. The relative productivity for entrants (ENTRPROD) is the mean value of productivity of entrants divided by the mean for all firms (including exiting firms) in the industry ${ }^{14}$. The same procedure is applied to the calculation of the relative productivity of incumbent firms (INCRPROD). Profitability is measured by total profits over total sales. The relative profitability of entrants (ENTRPROF) is the mean value of profitability of entrants divided by the mean for all firms in the industry. For incumbents, the relative profitability (INCRPROF) is measured likewise. In the table below the mean of these variables are presented for the three stages. Furthermore, the upper and lower 95\%confidence limits (CLM) of the means are reported.

\begin{tabular}{lllcc}
\hline Stage of industry & Variable & Mean & Lower 95\% CLM & Upper 95\% CLM \\
\hline Expansion & INCRPROD & 1.02 & 1.01 & 1.04 \\
& ENTRPROD & 1.05 & 1.02 & 1.08 \\
& INCRPROF & 1.08 & 0.87 & 1.29 \\
& ENTRPROF & 1.53 & 0.90 & 2.15 \\
Shake-out & & & & \\
& INCRPROD & 1.05 & 1.02 & 1.09 \\
& ENTRPROD & 1.05 & 0.92 & 1.17 \\
& INCRPROF & 0.95 & 0.77 & 1.13 \\
Contraction & ENTRPROF & 1.17 & 0.66 & 1.68 \\
& & & & 1.10 \\
& INCRPROD & 1.05 & 1.00 & 1.23 \\
& ENTRPROD & 1.10 & 0.98 & 1.47 \\
& INCRPROF & 1.20 & 0.93 & 2.85 \\
\hline
\end{tabular}

For each group of industries, incumbent firms are on average not more productive or profitable than surviving entrants. In expanding and in contracting industries,

\footnotetext{
${ }^{14}$ Here, unweighted means were used: the mean value of, for instance, entrants' productivity is the unweighted mean of all observations available for successful entrants within an industry. When weighted means are used, approximately the same results are observed. Still, unweighted means are preferred as they mitigate the effect of the appearance of very large firms in an industry, which in most cases are no entrants in this dataset.
} 
incumbents are on average even less productive than entrants, although the differences are not significant ${ }^{15}$. This result is very important, because it might indicate which part of Klepper's model is not applicable to manufacturing industries in general. The next section will return to this topic.

Hypothesis II.1 In expanding industries, a certain number of incumbents are replaced by a larger number of smaller entrants. In industries experiencing a shake-out, the largest firms expand their market shares at the expense of smaller firms.

Four measures are used. The first one is the number of entrants over the number of exiters (ENTEXT) per industry. Entrants are again defined as firms not present in 1978, but present in 1992. Exiters are firms present in 1978, but absent in 1992. The next two measures are the average sizes of entrants (ULTSZENT) and exiters (INISZEXT). The first one is the industrial mean of the 1992 size of entrants (in terms of the number of employees), the second one is the industrial mean of the 1978 size of exiters. For testing the second part of hypothesis II.6, the absolute change in the Herfindahl index (CHHERFIN) is used. ${ }^{16}$

\begin{tabular}{llccc}
\hline Stage of industry & Variable & Mean & Lower 95\% CLM & Upper 95\% CLM \\
\hline Expansion & ENTEXT & 2.21 & 1.81 & 2.61 \\
& ULTSZENT & 79.2 & 56.8 & 101.7 \\
& INISZEXT & 111.9 & 68.9 & 155.0 \\
& CHHERFIN & -2.39 & -4.46 & -0.32 \\
Shake-out & & & 0.49 & 0.80 \\
& ENTEXT & 0.64 & 48.5 & 148.8 \\
& ULTSZENT & 98.6 & 67.3 & 138.6 \\
& INISZEXT & 102.9 & -0.71 & 3.57 \\
Contraction & CHHERFIN & 1.42 & & 1.08 \\
& & & 0.30 & 75.8 \\
& ENTEXT & 0.69 & 49.6 & 187.2 \\
& ULTSZENT & 62.7 & 92.2 & 5.11 \\
\hline
\end{tabular}

The first part of this hypothesis is confirmed by the data. In expanding industries, entry and exit occur simultaneously, i.e., a number of exiting firms are replaced by a higher number of significantly ${ }^{17}$ smaller entrants. With regard to the second part of hypothesis II.6, some weak evidence is found. On average, the Herfindahl index increased slightly in shake-out industries, but the lower confidence limits are less than zero. An interesting observation is that in industries experiencing a shake-out, the ultimate size of entrants is approximately equal to the initial size of exiters.

\footnotetext{
${ }^{15}$ This is confirmed by a paired groups $t$ test. For each industry, the difference between INCPROD and ENTPROD and the difference between INCRPROF and ENTRPROF was calculated. Subsequently, for each stage the mean of these differences were computed. For each stage, the hypotheses that the true means of these differences are equal to zero could not be rejected.

${ }^{16}$ For each industry, the Herfindahl index is calculated as follows: 100* [sum of the squared market shares].

${ }^{17}$ As shown by a paired groups $t$ test, similar to the test applied to hypothesis I.5.
} 
Hypothesis III.1: The growth of continuing firms' market shares is positively related to their profit rates.

For each continuing firm present in the group of expanding and shake-out industries, the change in market share between 1978 and 1992 was calculated. Then, again for each firm, the average profit rate was calculated by the sum of real profits (between 1978 and 1992) divided by the sum of real sales over the same period. This average profit rate of each incumbent was then divided by the average industrial profit rate for continuing firms to calculate the relative profitability of each continuing firm.

To test hypothesis III.1, the correlation coefficient between the change in market share and the $\log$ of relative profitability was calculated. Although the coefficient is significantly positive, its value of 0.11 is not high. But despite this low value, the hypothesis is accepted.

Hypothesis III.2: Profit rates are higher in expanding industries than in industries experiencing a shake-out.

The profit rate is defined as total profits (before taxes) over total sales. Then for each industry the mean of these profit rates (MNRLPROF) is calculated.

\begin{tabular}{|c|c|c|c|c|c|}
\hline \multicolumn{2}{|c|}{ MNRLPROF $(\%)$} & \multicolumn{2}{c|}{ vs. Shake-out } & \multicolumn{2}{c|}{ vs. Contraction } \\
\hline $\begin{array}{c}\text { Stage of } \\
\text { industry }\end{array}$ & $\begin{array}{c}\text { Mean } \\
(\text { stderr })\end{array}$ & $\begin{array}{c}\text { F-statistic } \\
\text { (p-value) }\end{array}$ & $\begin{array}{c}\text { T-statistic } \\
(\mathrm{p} \text {-value })\end{array}$ & $\begin{array}{c}\text { F-statistic } \\
(\mathrm{p} \text {-value })\end{array}$ & $\begin{array}{c}\text { T-statistic } \\
(\mathrm{p} \text {-value })\end{array}$ \\
\hline Expansion & $\begin{array}{c}9.29 \\
(0.42)\end{array}$ & $\begin{array}{c}1.30 \\
(0.41)\end{array}$ & $\begin{array}{c}0.45 \\
(0.66)\end{array}$ & $\begin{array}{c}1.40 \\
(0.36)\end{array}$ & $\begin{array}{c}2.37 \\
(0.02)\end{array}$ \\
\hline Shake-out & 8.96 & & & 1.08 & 1.64 \\
& $(0.65)$ & & & $(0.84)$ & $(0.11)$ \\
\hline Contraction & 7.19 & & & & \\
& $(0.87)$ & & & & \\
\hline
\end{tabular}

Because the differences are insignificant between expansion and shake-out, hypothesis III. 2 is not accepted. Contracting industries exhibit the lowest profit rates, which are significantly lower than the profit rates of expanding industries.

Hypothesis III.3: The growth of market shares of continuing firms is higher in expanding industries than in industries experiencing a shake-out.

For testing this hypothesis, the same variables defined at hypothesis I.4 (MINCSHCH and DIFINCSH, both expressed in percentages) are used. 


\begin{tabular}{|c|c|c|c|c|c|}
\hline \multicolumn{2}{|c|}{ MINCSHCH $(\%)$} & \multicolumn{2}{c|}{ vs. Shake-out } & \multicolumn{2}{c|}{ vs. Contraction } \\
\hline $\begin{array}{c}\text { Stage of } \\
\text { industry }\end{array}$ & $\begin{array}{c}\text { Mean } \\
(\text { stderr })\end{array}$ & $\begin{array}{c}\text { F-statistic } \\
(\mathrm{p} \text {-value })\end{array}$ & $\begin{array}{c}\text { T-statistic } \\
(\mathrm{p} \text {-value })\end{array}$ & $\begin{array}{c}\text { F-statistic } \\
(\mathrm{p} \text {-value })\end{array}$ & $\begin{array}{c}\text { T-statistic } \\
(\mathrm{p} \text {-value })\end{array}$ \\
\hline Expansion & -0.44 & 1.22 & -2.48 & 3.16 & $-3.28^{*}$ \\
& $(0.32)$ & $(0.59)$ & $(0.02)$ & $(<0.01)$ & $(<0.01)$ \\
\hline Shake-out & 0.87 & & & 3.85 & $-1.98^{*}$ \\
& $(0.40)$ & & & $(<0.01)$ & $(0.06)$ \\
\hline Contraction & 3.00 & & & & \\
& $(1.00$ & & & & \\
\hline
\end{tabular}

* approximated

\begin{tabular}{|c|c|c|c|c|c|}
\hline \multicolumn{2}{|c|}{ DIFINCSH $(\%)$} & \multicolumn{2}{c|}{ vs. Shake-out } & \multicolumn{2}{c|}{ vs. Contraction } \\
\hline $\begin{array}{c}\text { Stage of } \\
\text { industry }\end{array}$ & $\begin{array}{c}\text { Mean } \\
(\text { stderr })\end{array}$ & $\begin{array}{c}\text { F-statistic } \\
(\mathrm{p} \text {-value) }\end{array}$ & $\begin{array}{c}\text { T-statistic } \\
(\mathrm{p} \text {-value })\end{array}$ & $\begin{array}{c}\text { F-statistic } \\
(\mathrm{p} \text {-value })\end{array}$ & $\begin{array}{c}\text { T-statistic } \\
(\mathrm{p} \text {-value })\end{array}$ \\
\hline Expansion & -9.20 & 1.04 & -5.43 & 1.69 & -8.42 \\
& $(2.12)$ & $(0.89)$ & $(<0.01)$ & $(0.16)$ & $(<0.01)$ \\
\hline Shake-out & 10.3 & & & 1.63 & -3.63 \\
& $(2.92)$ & & & $(0.25)$ & $(<0.01)$ \\
\hline Contraction & 29.5 & & & & \\
& $(4.78)$ & & & & \\
\hline
\end{tabular}

The tables show exactly the opposite of what is stated in hypothesis III.3. The mean of the growth of market shares of incumbents is significantly lower (it is even negative) in expanding industries than in shake-out industries. The highest values for these variables are found in contracting industries. Because the results are exactly opposite to what is stated in hypothesis III.3, this finding is very interesting and will therefore be explored in the next section.

Hypothesis IV.1: For each period, large firms are more productive and profitable than small firms.

The correlation coefficient between firm size (in terms of the log of sales) and productivity (real value added per employee) is equal to 0.40 for expanding industries, and 0.41 for shake-out industries, with both p-values far less than 0.01 . For the correlation between size and profitability (profits over sales), the coefficient is equal to 0.03 for both groups of industries (p-values again far less than 0.01). Although the values of the last correlation coefficient are low, these findings support the hypothesis that in every period large firms are more productive and profitable than small firms.

Before discussing the results in section 7, first a short summary of the results of this section will be given. The results of testing the first three hypotheses show that the process of entry is in line with Klepper's propositions. Annual entry rates and cumulative entry rates are higher, and infant mortality is lower in expanding industries than in industries experiencing a shake-out of firms. Apparently, for entrants it becomes more difficult to survive and grow as the industry matures. The model's explanation for this is that the advantage of incumbents over entrants grows over time. However, as the results of testing hypothesis I.5 show, this is not reflected by a higher 
productivity or profitability of continuing firms. In expanding industries, on average entrants are in fact more productive than incumbent firms.

No evidence was found for the fourth hypothesis: on average changes in market shares are very small for continuing firms, and about half of them actually lose market share. Weak evidence was found for hypothesis II.1 and III.1: in expanding industries a number of exiting firms are replaced by a higher number of smaller entrants, and in the group of shake-out industries the (on average) slightly increasing Herfindahl index suggests that large firms grow at the expense of small firms. Also a positive correlation was found between the growth of market share of continuing firms and their average profit rates. Hypothesis III. 2 could not be accepted, since on average the profit rates between the group of expanding industries and shake-out industries do not significantly differ. Hypothesis III.3 was rejected, because in expanding industries continuing firms on average lose market share, whereas in industries experiencing a shake-out they gain on average. The final hypothesis was accepted. Especially between labour productivity and the size of the firm (in terms of output) a fairly strong positive correlation was found.

\section{The sample reconsidered}

Returning to the three questions posed in the introduction of this paper, the analysis of section 6 allows for some preliminary answers. The answer to the first question is obviously yes: industries in different stages show different regularities. The second question (are the observed regularities in line with the regularities predicted by the model?) cannot be answered so easily, because the evidence is mixed. On the one hand, no (or only weak) evidence was found for the hypotheses that focused on the expansion of market shares of continuing firms, or on the differences of profit rates between expanding and shake-out industries. On the other hand, the test results of hypotheses I.1 to I.3 seem to confirm Klepper's prediction of a growing advantage of incumbents over entrants, since the results suggest that is it more difficult for small firms to enter, survive, and grow in industries experiencing a shake-out. Also, the replacement process in expanding industries (hypothesis II.1) is according to Klepper's model. Finally, large firms were found to be more productive than small firms. Hence, to some extent the observed regularities are in line with Klepper's predictions.

However, no evidence was found for that part of Klepper's model that actually explains the emerging regularities. It is dynamic increasing returns to technological change that drives Klepper's model, but on average incumbent firms were not found to be more productive or profitable than entrants. Therefore, the answer to the third question is no: although industries in different stages show different regularities, and although the observed (differences in) regularities are to some extent in line with Klepper's model, they cannot be explained by dynamic increasing returns to technological change.

Of course, this conclusion is only based on the means of the groups of expanding and shake-out industries: computed over 79 industries, incumbents are on average not more productive than entrants. However, out of these 79 industries, there are 36 industries in which incumbents are in fact more productive than entrants. It would be 
interesting to see whether this subgroup of industries perform better in terms of matching Klepper's model than the whole set of industries. Perhaps the hypotheses for which no or only weak evidence was found when the whole group of industries was considered, can be accepted when only those industries are considered in which incumbents perform better than entrants. If at the same time the acceptability of the hypotheses becomes less strong for the group of industries in which entrants perform better than incumbents, then this would suggest that dynamic increasing returns to technological change do explain the observed regularities, but only for a specific subset of industries.

Therefore, all industries which were expanding or experiencing a shake-out, are divided on the basis of the average productivity of entrants versus the average productivity of incumbents. ${ }^{18}$ If in an industry the labour productivity of incumbents is higher on average than the productivity of successful entrants, than the industry is labelled "Incumbent Favouring" (IF). Accordingly, the industry is labelled "Entrant Favouring" (EF) if the opposite holds. If this criterion is applied, then the group of expanding industries is divided in $29 \mathrm{EF}$ and $22 \mathrm{IF}$ industries and the group of industries experiencing a shake-out is divided in $14 \mathrm{EF}$ and $14 \mathrm{IF}$ industries. To see whether the regularities of the group of IF industries are more in line with the propositions of Klepper's model than the group of EF industries, the same hypotheses were tested again, but this time for the IF industries and the EF industries separately.

Hypothesis I.1: The entryrates in expanding industries are higher than in industries experiencing a shake-out.

\begin{tabular}{|c|c|c|c|c|}
\hline ENTRYRT $*$ & \multicolumn{3}{|c|}{ vs. Shake-out } \\
\hline $\begin{array}{c}\text { Type of } \\
\text { industry }\end{array}$ & $\begin{array}{c}\text { Stage of } \\
\text { industry }\end{array}$ & $\begin{array}{c}\text { Mean } \\
(\text { stderr })\end{array}$ & $\begin{array}{c}\text { F-statistic } \\
(\mathrm{p} \text {-value })\end{array}$ & $\begin{array}{c}\text { T-statistic } \\
(\mathrm{p} \text {-value })\end{array}$ \\
\hline IF & Expansion & $10.1(1.08)$ & $5.98(<0.01)$ & $3.57(<0.01)^{* *}$ \\
\hline & Shake-out & $5.81(0.55)$ & & \\
\hline EF & Expansion & $7.64(0.92)$ & $5.46(<0.01)$ & $0.88(0.38)^{* *}$ \\
\hline & Shake-out & $6.68(0.57)$ & & \\
\hline
\end{tabular}

For IF industry, the hypothesis is accepted: entry rates are significantly higher in expanding industries. This is not the case for EF industries, for which the hypotheses is hence not accepted.

\footnotetext{
${ }^{18}$ Because of the high dispersion of profit rates, preference was given to labour productivity as a measure of firm performance.
} 
Hypothesis I.2: Firms entering expanding industries have higher survival rates than firms entering shake-out industries.

\begin{tabular}{|c|c|c|c|c|}
\hline MEANMORT* & \multicolumn{2}{|c|}{} & \multicolumn{2}{|c|}{ vs. Shake-out } \\
\hline $\begin{array}{c}\text { Type of } \\
\text { industry }\end{array}$ & $\begin{array}{c}\text { Stage of } \\
\text { industry }\end{array}$ & $\begin{array}{c}\text { Mean } \\
\text { (stderr })\end{array}$ & $\begin{array}{c}\text { F-statistic } \\
\text { (p-value) }\end{array}$ & $\begin{array}{c}\text { T-statistic } \\
\text { (p-value) }\end{array}$ \\
\hline IF & Expansion & $59.8(5.75)$ & $1.18(0.81)$ & $-1.35(0.19)$ \\
\hline & Shake-out & $72.0(6.76)$ & & \\
\hline EF & Expansion & $56.3(4.18)$ & $1.01(1.00)$ & $-2.96(0.01)$ \\
\hline & Shake-out & $78.9(6.36)$ & & \\
\hline
\end{tabular}

* in percentages

For both IF and EF industries, the survival rates are on average higher in expanding industries than in shake-out industries. However, only for the EF industries the mortality rates differ significantly.

Hypothesis I.3: The collective share of all entrants at the end of the observation period is higher in expanding industries than in industries experiencing a shake-out.

\begin{tabular}{|c|c|c|c|c|}
\hline SLENRTCM $^{*}$ & \multicolumn{2}{|c|}{ vs. Shake-out } \\
\hline $\begin{array}{c}\text { Type of } \\
\text { industry }\end{array}$ & $\begin{array}{c}\text { Stage of } \\
\text { industry }\end{array}$ & $\begin{array}{c}\text { Mean } \\
\text { (stderr) }\end{array}$ & $\begin{array}{c}\text { F-statistic } \\
\text { (p-value) }\end{array}$ & $\begin{array}{c}\text { T-statistic } \\
\text { (p-value) }\end{array}$ \\
\hline IF & Expansion & $29.5(4.40)$ & $2.53(0.09)$ & $1.96(0.06)$ \\
\hline EF & Shake-out & $17.4(3.47)$ & & \\
\hline & Expansion & $33.8(2.90)$ & $1.16(0.71)$ & $2.01(0.05)$ \\
\hline & Shake-out & $23.3(4.49)$ & & \\
\hline
\end{tabular}

* in percentages

As the table shows, there is strong evidence that for both IF and EF industries the collective market share of entrants is higher in expanding industries than in shake-out industries.

Hypothesis I.4: Incumbents have a higher market share in 1992 than in 1978.

\begin{tabular}{clccc}
\hline Type of industry & Variable* $^{*}$ & Mean & Lower 95\% CLM & Upper 95\% CLM \\
\hline IF & MINCSHCH & 0.00 & -0.17 & 0.18 \\
& DIFINCSH & 0.17 & -5.80 & 6.14 \\
EF & MINCSHCH & -0.18 & -0.36 & 0.00 \\
& DIFINCSH & -4.35 & -9.87 & 1.17 \\
\hline
\end{tabular}

* in percentages

As in section 6, where this hypothesis was tested for the whole group of industries, this hypothesis is again not accepted, neither for IF industries, nor for EF industries. 
Hypothesis I.5: Incumbents are more productive and profitable than entrants, and the gaps between continuing firms and entrants are higher in shake-out industries than in expanding industries.

IF-industries

\begin{tabular}{lllcc}
\hline Stage of industry & Variable & Mean & Lower 95\% CLM & Upper 95\% CLM \\
\hline Expansion & INCRPROD & 1.07 & 1.04 & 1.09 \\
& ENTRPROD & 0.97 & 0.95 & 0.99 \\
& INCRPROF & 1.07 & 0.60 & 1.55 \\
& ENTRPROF & 1.88 & 0.39 & 3.38 \\
Shake-out & & & & \\
& INCRPROD & 1.08 & 1.05 & 1.11 \\
& ENTRPROD & 0.91 & 0.71 & 1.10 \\
& INCRPROF & 0.94 & 0.59 & 1.29 \\
& ENTRPROF & 0.61 & -0.17 & 1.40 \\
\hline
\end{tabular}

EF-industries

\begin{tabular}{lllcc}
\hline Stage of industry & Variable & Mean & Lower 95\% CLM & Upper 95\% CLM \\
\hline Expansion & INCRPROD & 0.99 & 0.97 & 1.01 \\
& ENTRPROD & 1.12 & 1.08 & 1.15 \\
& INCRPROF & 1.08 & 0.96 & 1.20 \\
& ENTRPROF & 1.26 & 1.12 & 1.40 \\
Shake-out & & & & \\
& INCRPROD & 1.03 & 0.96 & 1.09 \\
& ENTRPROD & 1.20 & 1.06 & 1.34 \\
& INCRPROF & 0.96 & 0.81 & 1.10 \\
& ENTRPROF & 1.77 & 1.23 & 2.31 \\
\hline
\end{tabular}

The first part of hypothesis I.5 has become trivial, since the average productivity of entrants and incumbents are now used as the criteria for dividing the industries in IF and EF industries. But the second part of hypothesis I.5, stating that the productivity gap between continuing firms and entrants is higher in shake-out industries than in expanding industries, is now accepted for the IF industries. In the expanding stage, incumbents are about 10 percent more productive than successful entrants, during the shake-out stage this difference increases to 17 percent. Profit rates do not significantly differ between continuing firms and entrants in IF industries, however in EF industries entrants are in both stages significantly more profitable than incumbents ${ }^{19}$.

${ }^{19}$ As shown by a paired groups $t$ test, similar to the test applied to hypothesis I.5. 
Hypothesis II.1: In expanding industries, a certain number of incumbents are replaced by a larger number of smaller entrants. In industries experiencing a shake-out, the largest firms expand their market shares at the expense of smaller firms.

Incumbent Favouring industries

\begin{tabular}{llccc}
\hline Stage of industry & Variable & Mean & Lower 95\% CLM & Upper 95\% CLM \\
\hline Expansion & ENTEXT & 2.50 & 1.73 & 3.26 \\
& ULTSZENT & 66.9 & 54.1 & 79.6 \\
& INISZEXT & 97.6 & 61.9 & 133 \\
& CHHERFIN & -2.37 & -4.87 & 0.12 \\
Shake-out & & & \\
& ENTEXT & 0.59 & 0.42 & 0.77 \\
& ULTSZENT & 126 & 26.9 & 226 \\
& INISZEXT & 111 & 43.8 & 179 \\
& CHHERFIN & 1.50 & -1.08 & 4.07 \\
\hline
\end{tabular}

Entrant Favouring industries

\begin{tabular}{llccc}
\hline Stage of industry & Variable & Mean & Lower 95\% CLM & Upper 95\% CLM \\
\hline Expansion & ENTEXT & 2.00 & 1.56 & 2.44 \\
& ULTSZENT & 88.6 & 49.5 & 127 \\
& INISZEXT & 122 & 50.0 & 195 \\
& CHHERFIN & -2.40 & -5.64 & 0.85 \\
Shake-out & & & & \\
& ENTEXT & 0.70 & 0.40 & 0.99 \\
& ULTSZENT & 68.4 & 53.9 & 83.0 \\
& INISZEXT & 94.4 & 59.4 & 129 \\
& CHHERFIN & 1.36 & -2.44 & 5.16 \\
\hline
\end{tabular}

The results show that for both IF and EF industries, in expanding industries, a number of exiters are replaced by a larger number of smaller entrants. Only weak evidence is found for an expansion of large firms at the expense of smaller firms in the shake-out stage. Hence, the results are quite similar to the results of testing this hypothesis in section 6 .

Hypothesis III.1: The growth of continuing firms' market shares is positively related to their profit rates.

Correlation coefficient between the change in market share and the log of relative profitability for ( $p$-value between brackets):

IF-industries: $0.12(<0.01)$

EF-industries: $0.11(<0.01)$

Again, hardly any difference between IF and EF industries. For both types of industries the hypothesis is accepted therefore. 
Hypothesis III.2: Profit rates are higher in expanding industries than in industries experiencing a shake-out.

\begin{tabular}{|c|c|c|c|c|}
\hline MNRLPROF* & \multicolumn{2}{|c|}{ vs. Shake-out } \\
\hline $\begin{array}{c}\text { Type of } \\
\text { industry }\end{array}$ & $\begin{array}{c}\text { Stage of } \\
\text { industry }\end{array}$ & $\begin{array}{c}\text { Mean } \\
\text { (stderr })\end{array}$ & $\begin{array}{c}\text { F-statistic } \\
\text { (p-value) }\end{array}$ & $\begin{array}{c}\text { T-statistic } \\
\text { (p-value) }\end{array}$ \\
\hline IF & Expansion & $9.51(0.67)$ & $1.67(0.29)$ & $-0.06(0.96)$ \\
\hline EF & Shake-out & $9.58(1.09)$ & & \\
\hline & Expansion & $9.12(0.55)$ & $1.22(0.72)$ & $0.85(0.40)$ \\
\hline & Shake-out & $8.33(0.71)$ & & \\
\hline
\end{tabular}

$*$ in percentages

For both types of industries this hypothesis is not accepted. Also here, dividing the industries in IF and EF does not alter the conclusion drawn from analyzing the whole group of industries.

Hypothesis III.3: The growth of market shares of continuing firms is higher in expanding industries than in industries experiencing a shake-out.

\begin{tabular}{|c|c|c|c|c|}
\hline MINCSHCH* & \multicolumn{2}{|c|}{ vs. Shake-out } \\
\hline $\begin{array}{c}\text { Type of } \\
\text { industry }\end{array}$ & $\begin{array}{c}\text { Stage of } \\
\text { industry }\end{array}$ & $\begin{array}{c}\text { Mean } \\
(\text { stderr })\end{array}$ & $\begin{array}{c}\text { F-statistic } \\
\text { (p-value) }\end{array}$ & $\begin{array}{c}\text { T-statistic } \\
\text { (p-value) }\end{array}$ \\
\hline IF & Expansion & $-0.15(0.69)$ & $1.93(0.23)$ & $-1.19(0.24)$ \\
\hline & Shake-out & $1.05(0.63)$ & & \\
\hline EF & Expansion & $-0.66(0.23)$ & $2.32(0.06)$ & $-2.81(0.01)$ \\
\hline & Shake-out & $0.70(0.51)$ & & \\
\hline
\end{tabular}

* in percentages

\begin{tabular}{|c|c|c|c|c|}
\hline DIFINCSH* & \multicolumn{2}{|c|}{} & \multicolumn{2}{c|}{ vs. Shake-out } \\
\hline $\begin{array}{c}\text { Type of } \\
\text { industry }\end{array}$ & $\begin{array}{c}\text { Stage of } \\
\text { industry }\end{array}$ & $\begin{array}{c}\text { Mean } \\
(\text { stderr })\end{array}$ & $\begin{array}{c}\text { F-statistic } \\
\text { (p-value) }\end{array}$ & $\begin{array}{c}\text { T-statistic } \\
(\mathrm{p} \text {-value })\end{array}$ \\
\hline IF & Expansion & $-7.25(3.39)$ & $1.34(0.60)$ & $-3.69(<0.01)$ \\
\hline EF & Shake-out & $11.8(3.69)$ & & \\
\hline & Expansion & $-10.7(2.72)$ & $1.39(0.45)$ & $-3.84(<0.01)$ \\
\hline & Shake-out & $8.76(4.63)$ & & \\
\hline
\end{tabular}

* in percentages

This hypothesis remains rejected, for both IF and EF industries. In expanding industries, incumbents lose market share, whereas they gain in shake-out industries. 
Hypothesis IV.1: For each period, large firms are more productive and profitable than small firms.

The correlation coefficients between firm size and productivity:

\begin{tabular}{clcr}
\hline Type of industry & Stage & Correlation coefficient & P-value \\
\hline IF & Expansion & 0.48 & $<0.01$ \\
& Shake-out & 0.54 & $<0.01$ \\
EF & Expansion & 0.39 & $<0.01$ \\
& Shake-out & 0.36 & $<0.01$ \\
\hline
\end{tabular}

With regard to productivity, this hypothesis remains accepted for both type of industries. However, some difference can be observed now between the strength of the correlation of IF and EF industries. The correlation between firm size and productivity is stronger for IF industries than for EF industries. Furthermore, within the IF industries the correlation coefficient is higher for shake-out industries than for expanding industries, as opposed to the EF industries.

The correlation coefficients between firm size and profitability:

\begin{tabular}{clcr}
\hline Type of industry & Stage & Correlation coefficient & P-value \\
\hline IF & Expansion & -0.01 & 0.06 \\
& Shake-out & 0.04 & $<0.01$ \\
EF & Expansion & 0.07 & $<0.01$ \\
& Shake-out & -0.10 & $<0.01$ \\
\hline
\end{tabular}

With regard to profitability however, hypothesis IV.1 cannot be accepted for both IF and EF industries. We can even see a significant negative correlation between size and profitability for EF industries experiencing a shake-out.

The main conclusion from testing the hypotheses for IF and EF industries separately is that in general all previously accepted hypotheses are still accepted and all previously rejected hypotheses (accept for the now trivial hypothesis I.5) are still rejected. It is not the case that the group of industries in which incumbents are more productive than entrants shows more resemblance to Klepper's model than the group for which the opposite holds, since both groups show approximately the same regularities. Therefore, the conclusion stated at the beginning of this section, still holds. As Klepper's model predicts, there appears to be a growing advantage of incumbents over entrants, however there is no evidence that this is due to dynamic increasing returns to technological change.

This evidence for a growing advantage of incumbents over entrants becomes even stronger when the group of contracting industries is taken into account as well. When the variables used to test hypothesis I.4 were disaggregated to test hypothesis III.3, it was shown that, contrary to what is stated in hypothesis III.3, incumbents in general lose market share in expanding industries, and gain a considerable market share in contracting industries. Continuing firms seem to benefit only partly from the growth in total output, but this situation seems to be reversed in declining industries, i.e., 
continuing firms are apparently only partly affected by declining aggregate output. To show this more clearly, two variables are calculated for each industry and listed below. The first one is growth rate (between 1978 and 1992) of the real sales of all continuing firms together (GRTIRSLS). The second variable is the mean of growth rates of real total industrial output (GRRATE).

\begin{tabular}{lllcc}
\hline Stage of industry & Variable & Mean & Lower 95\% CLM & Upper 95\% CLM \\
\hline Expansion & GRRATE & 0.91 & 0.72 & 1.10 \\
& GRTIRSLS & 0.52 & 0.42 & 0.62 \\
Shake-out & GRRATE & 0.21 & 0.12 & 0.29 \\
& GRTIRSLS & 0.44 & 0.30 & 0.58 \\
Contraction & GRRATE & -0.41 & -0.51 & -0.33 \\
& GRTIRSLS & 0.20 & -0.28 & 0.68 \\
\hline
\end{tabular}

In expanding industries, total industrial output grows by $91 \%$ on average. The collective sales of continuing firms, however, grow only by $52 \%$. Apparently, continuing firms do benefit from the growth of the industry, but their collective share grows at a slower rate than total industrial output. But in contracting industries, the mean growth rate of total industrial output is - $41 \%$, whereas continuing firms together increase their sales by $20 \%$ on average (the standard error is quite high, though). Hence, there seems to be evidence that continuing firms only partly benefit from the growth of the industry when the industry is in its expanding stage. However, in contracting industries, continuing firms perform relatively well in terms of their aggregate sales, despite the fact that on average the entrants are more productive than incumbents.

As mentioned before, these empirical regularities are not in line with Klepper's model. However, the significant differences between the groups of industries in different stages that were observed for many of the variables, indicate that distinguishing industries on the basis of their evolutionary stage still makes sense. Furthermore, there is some evidence for a growing advantage of incumbents over entrants, even in industries in which entrants are more productive than incumbents on average. Seemingly, the growing advantage of incumbents stems from other sources as well.

Perhaps earlier work on the product life cycle, interpreted in a broader way, could help to identify these sources. For instance Klepper and Graddy (1990), in their discussion of qualitative regularities observed in empirical studies of development of new industries, state that the initial uncertainty that characterizes new industries "...abates as 'dominant designs' emerge for various features of the product”. However, the initial uncertainty does not only have to occur with respect to the design of the products, but might also occur with respect to a number of other issues, like commercial relationships and production techniques. If survival and growth depend on the fitness of a firm into the typical structure of production techniques and commercial relationships of an industry, then the firms that fit and operate within such an industrial network are able to increase their competitiveness vis-à-vis firms outside the network. Since it is unlikely that in the early stages of the evolution of industries the 
industrial networks have already emerged, continuing firms initially do not have a clear advantage over entering firms. But as soon as the emergence of networks sets in, possibly causing a shake-out of firms, continuing firms operating within these networks achieve a growing advantage over entrants. And as the industrial network reinforces itself in time, because of cumulative learning processes and declining transaction costs, it may also explain why the relative performance of continuing firms is highest in contracting industries, without those firms being technologically superior to entrants.

\section{Conclusions}

Although the model by Klepper (1996) is primarily intended to depict the evolution of technologically progressive industries, this paper has shown that applying the model to manufacturing industries in general, i.e., without any reference to their technological progressiveness, provides some interesting results. First, this paper has shown that significant differences can be observed between groups of industries which are in different stages of their evolution. Second, many of the observed regularities are in line with Klepper's model, implying that the advantage incumbent firms have over entrants grows as the industry matures.

However, the third result is that this advantage is seemingly not due to increasing dynamic returns from technological change, as predicted by Klepper (1996), because this (increasing) advantage is neither reflected by a higher labour productivity of incumbents, nor by higher profit rates. Even after breaking up the group of total industries in a group of industries in which the average productivity of incumbents is higher than the productivity of entrants, and a group in which the opposite holds, the outcomes of testing the hypotheses were approximately the same as when tested for the whole group. Apparently, there are also other factors than increasing returns from technological change that explain the increasing competitiveness of incumbent firms.

One of these factors might be the emergence of networks, consisting of the links that firms build up and maintain with their customers, their (financial) suppliers and other relevant actors. Initially, in the absence of such a network, incumbents do not have a clear advantage over entrants, but as the industry matures and networks emerge, firms within a network are able to increase their competitiveness vis-à-vis firms outside the network. This process can both explain a shake-out of firms, as well as the relative success of incumbent firms in later stages of industry evolution. 


\section{References}

Abernathy, W. and Utterback, J. (1978): "Patterns of Industrial Innovation". Technology Review 80: 41-47.

Acs, Z. and Audretsch, D. (1991): “Technological Regimes, Learning and Industry Turbulence". Berlin, mimeo.

Audretsch, D. (1987): “An Empirical Test of the Industry Life Cycle". Weltwirtschaftliches Archiv 123 (2): 297-308.

Baldwin, J. (1995): "The Dynamics of Industrial Competition: A North American Perspective". Cambridge: Cambridge University Press, 1995.

Breschi et.al. (1996): “Technological Regimes and Schumpeterian Patterns of Innovation". Paper prepared for the Meeting of the Josef A. Schumpeter Society, Stockholm, June 1996.

Dosi, G. (1988): "Sources, Procedures and Microeconomic Effect of Innovation". Journal of Economic Literature 26: 1120-1171.

Flaherty, M. (1980): "Industry Structure and Cost-Reducing Investment." Econometrica 48 (5): 1187-1209.

Gort, M. and Klepper, S. (1982): "Time paths in the diffusion of product innovations". The Economic Journal 92: 630-653.

Hayes, R. and Wheelwright, S. (1979a): "Link Manufacturing Process and Product Life Cycles". Harvard Business Review 57: 133-140.

Hayes, R. and Wheelwright, S. (1979b): "The Dynamics of Process-Product Life Cycles”. Harvard Business Review 57: 127-136.

Klepper, S. (1996): "Entry, Exit, Growth, and Innovation over the Product Life Cycle". The American Economic Review 86 (3): 562-583.

Klepper, S. and Graddy, E. (1990): "The evolution of new industries and the determinants of market structure". RAND Journal of Economics 21 (1): 27-44.

Levitt, T. (1965): "Exploit the Product Life Cycle". Harvard Business Review 18: 8194.

Schumpeter J. (1939): "Business Cycles: a Theoretical, Historical and Statistical Analysis of the Capitalist Process". McGraw-Hill, New York.

Utterback, J. and Abernathy, W. (1975): "A Dynamic Model of Process and Product Innovation." Omega 3 (6): 639-656. 


\section{Appendix 1: list of sampled industries (nec: not elsewhere classified)}

\section{Expanding industries:}

Incumbent favouring:

Manufacture of bakery products

Manufacture of malt liquors and malt

Finishing of textiles

Manufacture of made-up textile articles, except apparel

Manufacture of corrugated paper and paperboard

Offset printing

Other printing

Other publishing

Manufacture of synthetic resin

Manufacture of dye-stuffs and colouring matters

Manufacture of metal furniture

Forging, treatment and coating of metals

Manufacture of agricultural machinery

Manufacture of machinery for packing and wrapping

Manufacture of machinery for manufacturers of rubber and plastic products

Manufacture of machinery for textile and apparel

Manufacture of pumps, compressors, taps and valves

Appendage

Manufacture of machinery nec

Manufacture of electricity distribution and control apparatus

Manufacture of motor vehicles

Manufacture of parts and accessories for motor vehicles

Entrant favouring:

Processing and preserving of fish and fish products

Manufacture of other food products nec

Manufacture of carpets and rugs

Manufacture of other articles of paper and paperboard

Chemigrafical and fotolithografical firms

Publishing of books

Manufacture of chemical raw materials nec

Manufacture of paints, varnishes and similar coatings, printing ink

Manufacture of pharmaceuticals and medicinal chemicals

Manufacture of other chemical products nec

Manufacture of plastic products

Manufacture of other non-metallic mineral products nec

Manufacture of glass and glass products

Iron, steel and non-ferrous metal foundries

Manufacture of tanks, reservoirs and pipe-lines

Manufacture of steel and non-ferrous metal doors, windows, walls and the like

Metal construction nec

Manufacture of machine-tools

Manufacture of machinery for food, beverage and tobacco processing

Manufacture of lifting and handling equipment

Manufacture of machinery for chemical cleaning, washing, leather and leather products, paper and paper products and printing

Manufacture of fans, refrigerating and freezing equipment

Manufacture of machine parts nec

Manufacture of electric motors, generators and transformers

Manufacture of other electrical equipment nec

Manufacture of trailers and semi-trailers

Manufacture of bodies for motor vehicles

Manufacture and repairment of aircraft

Manufacture of transport equipment nec 


\section{Shake-out industries:}

Incumbent favouring:

Manufacture of grain mill products

Manufacture of sugar, cacao, chocolate and sugar confectionery

Manufacture of prepared animal feeds

Manufacture of other products of wood, manufacture of articles of cork, straw and plaiting materials

Manufacture of furniture, except metal furniture

Manufacture of paper and paperboard

Printing of newspapers

Publishing of newspapers

Manufacture of rubber products

Manufacture of cement and lime

Manufacture of articles of concrete and cement

Manufacture of metal fasteners, cables, springs and the like

Manufacture of heating and boilers, except electrical

Manufacture of other fabricated metal products nec

Entrant favouring:

Production, processing and preserving of meat and meat products

Manufacture of vegetable and animal oils and fats

Processing and preserving of fruit and vegetables

Manufacture of soft drinks

Manufacture of tobacco products

Manufacture of other textiles nec

Tanning and dressing of leather

Manufacture of luggage, handbags and the like, saddlery and harness

Manufacture of wooden containers

Manufacture of soap and detergents, cleaning and polishing preparations, perfumes and toilet preparations

Manufacture of chemical pesticides

Forging, pressing, stamping and roll-forming of metal

Machine repairment nec

Manufacture of motorcycles and bicycles

\section{Consolidating industries:}

Incumbent favouring:

Bookbinding

Manufacture of ceramics

Manufacture of basic metals

Manufacture of bearings, gears, gearing and driving elements

Entrant favouring:

Carpentry and manufacture of densified wood and parquet flooring blocks

Manufacture of tools and machinery for metallurgy 


\section{Contracting industries:}

Incumbent favouring:

Manufacture of dairy products

Distilling, rectifying and blending of spirits; ethyl alcohol production

Manufacture of bricks and tiles

Manufacture of metal packings

Manufacture of office machinery

\section{Entrant favouring:}

Preparation and spinning of wool fibres, weaving of wool

Preparation and spinning of cotton fibres, weaving of cotton

Manufacture of tricot and stockings

Manufacture of wearing apparel, dressing and dyeing of fur

Manufacture of footwear

Sawmilling and planing of wood, manufacture of veneer sheets, plywood, laminboard, particle board and other panels and boards

Printing of books

Manufacture of machinery for petrochemical, chemical and pharmaceutical industries

Manufacture of machinery for wood and furniture

Manufacture of engines and turbines, except aircraft, vehicle and cycle engines

Manufacture of weighing machinery and domestic appliances, except electrical

Building and repairing of ships and boats

\section{Other industries:}

Incumbent favouring:

Manufacture of insulated wire and cable

Entrant favouring:

Publishing of periodicals

Manufacture of fertilizers

Manufacture of machinery for mining, construction, building materials and metallurgy 